Article

\title{
Feeding Behavior, Shrinking, and the Role of Mucus in the Cannonball Jellyfish Stomolophus sp. 2 in Captivity
}

\author{
Alicia Verónica Camacho-Pacheco ${ }^{1}\left(\mathbb{D}\right.$, Laura Cristina Gómez-Salinas ${ }^{2}\left(\mathbb{D}\right.$, Miguel Ángel Cisneros-Mata ${ }^{3, *(\mathbb{D})}$ \\ Demetrio Rodríguez-Félix ${ }^{3}$, Lourdes Mariana Díaz-Tenorio ${ }^{1}$ and Marco Linné Unzueta-Bustamante ${ }^{4}$
}

1 Departamento de Biotecnología y Ciencias Alimentarias, Instituto Tecnológico de Sonora (ITSON), Obregon Sonora 85860, Mexico; acamacho1514@gmail.com (A.V.C.-P.); lourdes.diaz@itson.edu.mx (L.M.D.-T.)

2 Facultad de Medicina Veterinaria y Zootecnia, Universidad Nacional Autónoma de Mexico (UNAM), Mexico City 04510, Mexico; cristina.gomez.laura@gmail.com

3 Dirección General de Investigación Pesquera del Pacífico, Centro Regional de Investigación Acuícola y Pesquera (CRIAP), Guaymas 85400, Mexico; deme771@hotmail.com

4 Instituto de Acuacultura del Estado de Sonora (IAES), Hermosillo 83280, Mexico; linne.unzueta2021@gmail.com

* Correspondence: miguel.cisneros@inapesca.gob.mx

Citation: Camacho-Pacheco, A.V.; Gómez-Salinas, L.C.; Cisneros-Mata, M.Á.; Rodríguez-Félix, D.;

Díaz-Tenorio, L.M.;

Unzueta-Bustamante, M.L. Feeding Behavior, Shrinking, and the Role of Mucus in the Cannonball Jellyfish Stomolophus sp. 2 in Captivity. Diversity 2022, 14, 103. https:// doi.org/10.3390/d14020103

Academic Editors: Michael Wink and Bert W. Hoeksema

Received: 16 December 2021

Accepted: 28 January 2022

Published: 31 January 2022

Publisher's Note: MDPI stays neutral with regard to jurisdictional claims in published maps and institutional affiliations.

Copyright: (C) 2022 by the authors. Licensee MDPI, Basel, Switzerland. This article is an open access article distributed under the terms and conditions of the Creative Commons Attribution (CC BY) license (https:// creativecommons.org/licenses/by/ $4.0 /)$.

\begin{abstract}
The importance of mucus produced by jellyfish species remains as understudied as their feeding behavior. Here, we study medusae under captivity, ascertain the role of mucus, and describe its feeding behavior. Between February and March 2019, live adult cannonball jellyfish, Stomolophus sp. 2, were collected in Las Guásimas Bay (Gulf of California, Mexico) and were offered fish eggs, mollusk "D" larvae, or Artemia nauplii in 4-day trials. Descriptions of feeding structures were provided for S. sp. 2. Digitata adhere food and scapulets fragment them, which, driven by water flow, pass via transport channels to the esophagus and the gastrovascular chamber where food is digested. Due to stress by handling, medusae produced mucus and water, lost feeding structures, and decreased in size. Based on our observations and a thorough literature review, we conclude that the production of mucus in S. sp. 2 plays several roles, facilitating capture and packing of prey, acting as a defense mechanism, and facilitating sexual reproduction; the latter improves the likelihood of a population persisting in the long run, because fertilized oocytes in mucus transform to planulae, settle, and transform into asexually reproducing polyps. Polyps live longer than the other life stages and are more resistant to adverse environmental conditions than the medusoid sexual stage.
\end{abstract}

Keywords: loss of feeding structures; size reduction; mucus; stress by manipulation; gulf of California

\section{Introduction}

Worldwide, the number of studies on medusae species are increasing due to their massive irruptions occurring in several places [1,2]. These events are attributed to factors such as overfishing of their competitors, natural predators [1-4], eutrophication of coastal waters [5], global ocean sprawl in artificial structures [6,7], alterations in flow of rivers [8,9], and climate change [10-14]. Jellyfish aggregations play important roles in marine ecosystems; during blooms, they can exhaust local plankton communities and impact wider trophic webs [15-17]. Most cnidarian medusa, such as scyphozoan (jellyfish) and cubozoan (box jellies) species, reproduce sexually and asexually. In general, asexual reproduction involves budding and strobilation of benthic polyps, while sexual reproduction entails female and male release of ova and sperm in the water during their breeding season [18-21].

Medusae are voracious predator species with various feeding strategies [22-25]. The feeding process in medusae relates to their anatomy, which results in species-specific differences in capture and ingestion modes. Cyanea capillata and Aurelia aurita have been reported to capture prey using tentacles, where prey species are attached and subsequently transported to the oral lobes to be digested [26]. However, Rhizostomae jellyfish, such 
as Stomolophus meleagris, do not have marginal tentacles; therefore, structures such as the manubrium, oral arms, and scapulets maintain contact with food through the mucus and nematocyst [25,27-29]. Nemopilema nomurai presents pores in the oral arms and scapulets, that limit prey size [28]. Finger-like projections (digitate) [30] are also observed in these structures; they paralyze prey [28] to retain food particles [31] and carry them through the pores $[28,30]$.

A notable feature of jellyfish species is mucus production, a viscous substance secreted as a stress response [32]. In $A$. aurita, the mucus is composed of proteins, lipids, and carbohydrates [33]. In Cnidaria, approximately $95 \%$ of the total wet mass of mucus is water, $3 \%$ mucin glycoproteins, and $2 \%$ cellular debris and water-soluble proteins [34]. A. aurita has mucus-producing cells that occur over the epidermis in ciliated areas and the gastric cavity, specifically in the villi's apical region and cavity wall $[27,33]$.

In the order Rhizostomae, the mucus can facilitate feeding [5], although its precise role and function are unclear. For scyphozoans, including $S$. meleagris, it was found that the mucus contained nematocysts and toxins which serve defensive purposes [35]. In the mucus of the jellyfish Cassiopea xamachana, mobile cellular structures were identified which trap and paralyze prey [36]. On the other hand, in Pelagia noctiluca, mucus serves to increase the likelihood of fertility [37].

Mucus contributes to other non-physiological functions. In previous studies using Aurelia coerulea, it was shown that mucus works as a "cleaner", preventing bacteria and debris accumulation on the surface $[32,33]$. Another novel role was hypothesized; mucus could be related to recruitment of a bacterial microbiome, as it can trap microbes from surroundings to colonize surface or gastric cavity [38]. It is essential to consider microbiome since it can be beneficial because some bacteria can synthetize antimicrobial compounds, which are helpful for jellyfish as the first defense against infections [34]. Finally, as prey and bacteria adhered to mucus, other compounds and microplastics were attached [33,39]. This could represent a problem to medusae, because they can accumulate in their bodies; or be beneficial, if used as a vehicle to remove pollutants from seawater [33].

The study of basic jellyfish biology is crucial to understand their role in the ecosystem and the importance and long-term adaptation to variable environments. In some commercially important species, such as the genus Stomolophus, the roles of mucus have not been thoroughly documented. In the present work, mucus production of a cannonball jellyfish $S$. sp. 2 was carefully observed to answer the question, "What might be its role(s) in the life history of the species?"

\section{Materials and Methods}

During February and March 2019, 54 live specimens of blue cannonball jellyfish (Stomolophus sp. 2 sensu Gómez Daglio and Dawson [40]) were hand-picked outside Las Guásimas coastal lagoon $\left(27^{\circ} 51^{\prime} \mathrm{N}, 110^{\circ} 35^{\prime} \mathrm{W}\right)$ in the Gulf of California, on board commercial fishing boats. Medusae samples were transferred for experimentation to the Center for Reproduction of Marine Species of the State of Sonora (CREMES) laboratory in Kino Bay $\left(28^{\circ} 52^{\prime} 29^{\prime \prime} \mathrm{N}, 112^{\circ} 01^{\prime} 54^{\prime \prime} \mathrm{W}\right)$. For transportation, medusae were placed in plastic bags within 19 L buckets, each bag with $10 \mathrm{~L}$ filtered $(5 \mu \mathrm{m})$ seawater, $100 \%$ saturated with oxygen. The smallest specimens measured $80 \mathrm{~mm}$ bell diameter (BD). Previous histological works indicate that males and female blue cannonball jellyfish of this size range are sexually mature [41]. We decided to work with mature medusae to avoid potential confusion if immature organisms were also used, and because commercial catch of immature medusae is forbidden by Mexican law.

Previously, a simple and inexpensive experimental aquarium system (Figure 1) was developed by the authors to maintain medusae under controlled conditions. Our system was designed specifically to avoid physical damage to the umbrella of medusae. This was done as an alternative to the relatively expensive Kreisel tank, commonly used to maintain live medusae because of the laminar flow it produces (e.g., [42,43]). The system consisted of an $8 \mathrm{~L}$ cylindric plastic bucket placed inside a $20 \mathrm{~L}$ plastic bucket. Two equidistant, circular 
holes $(2.54 \mathrm{~cm}$ in diameter) were drilled in the inner bucket $5 \mathrm{~cm}$ below the upper rim. This created, by negative air pressure, a gentle water flow towards the inner bucket. Then, $7 \mathrm{~L}$ of seawater were poured into the inner bucket, where two medusae were placed, while the outer bucked contained $4 \mathrm{~L}$ of seawater.

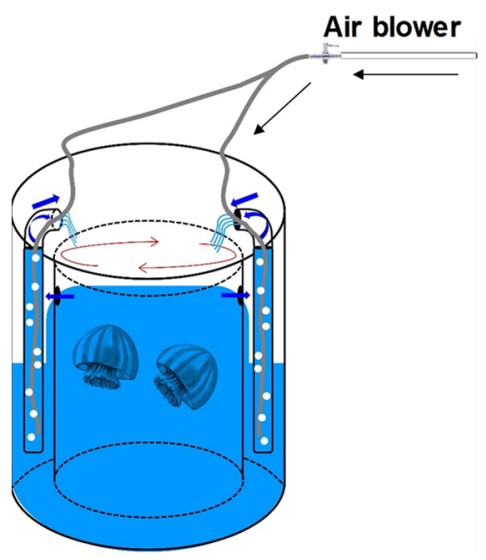

Figure 1. Schematics of the feeding assay system developed for Stomolophus sp. 2. Black straight arrows on top indicate air flow; red curved arrows in the inner container indicate water flow; straight short blue arrows indicate water cascading.

Aeration and negative pressure were generated using two plastic hoses introduced in $1.25 \mathrm{~cm}$-PVC tubes. Two $90^{\circ}$ PVC elbows were placed in the same direction, parallel to the inner bucket wall. This array provided a slow unidirectional water flow which in a few min created a water circulation with slight surface bubbling caused by the water cascading on each side at roughly $19 \mathrm{~mL} / \mathrm{s}$ (Figure 1 ).

When jellyfish specimens arrived at CREMES, they were kept under a period of starvation for $24 \mathrm{~h}$ to eliminate their gastric content. This time of acclimatation was chosen after preliminary trials, where it was observed that $48 \mathrm{~h}$ of starvation caused medusae to lose their feeding structures (see below for details). During this $24 \mathrm{~h}$ period, as well as the feeding essays, two full water exchanges were completed with filtered $(10,5$, and $1 \mu \mathrm{m}$ ) and-UV sterilized seawater, at an average temperature of $22.5^{\circ} \mathrm{C}, 4.2 \mathrm{mg} / \mathrm{L}$ oxygen concentration, and 36 PSU.

\subsection{Feeding Essays}

All specimens were measured on their bell diameters (BD) upon arrival to the laboratory and at the end of the essays. To conduct this measurement, medusae were held vertically by their oral arms (Figure 2A), and using a vernier, the BD was measured (1 $\mathrm{mm}$ precision). Most medusae were $80-90 \mathrm{~mm}$ in $\mathrm{BD}($ mean $=87 \mathrm{~mm}$, $\mathrm{sd}=4.8 \mathrm{~mm})$; in the few cases where we had a $100 \mathrm{~mm}$ BD individual, we paired it with a smaller one to avoid crowding as much as possible. It is important to note that the sex of adult cannonball jellyfish cannot be determined by eye; therefore, some tanks contained only males, others only females, and in some both sexes coincided. Each feeding essay was done on a separate week (Table 1). In week 1 , six containers (six replicates) were provided of Artemia nauplii, each container with two medusae ( $n=12$ in total). At the same time, three containers were controls without food, each container with two medusae ( $n=6$ in total). The second week, the experiment design was the same, but with changed food item (mollusk " $\mathrm{D}$ " larvae); the third week, the same experimental design was set up for Totoaba macdonaldi fish eggs. This gave a total of 18 medusae each week (12 medusae per treatment and 6 for the controls); however, due to an involuntary omission, we only measured 16 control individuals at the end of the experiment. Over a period of three days after the $24 \mathrm{~h}$ period of gastric content depuration, medusae were fed every $12 \mathrm{~h}$ immediately after exchanging water and debris. During cleaning of the tanks, medusae were manually transferred to fishbowls with gentle surface aeration, and thereafter, they were returned to the essay tanks. This 
cleaning process lasted between 30 to 45 min for each essay tank. Table 1 describes the feeding treatment of the essays.

\section{(A)}
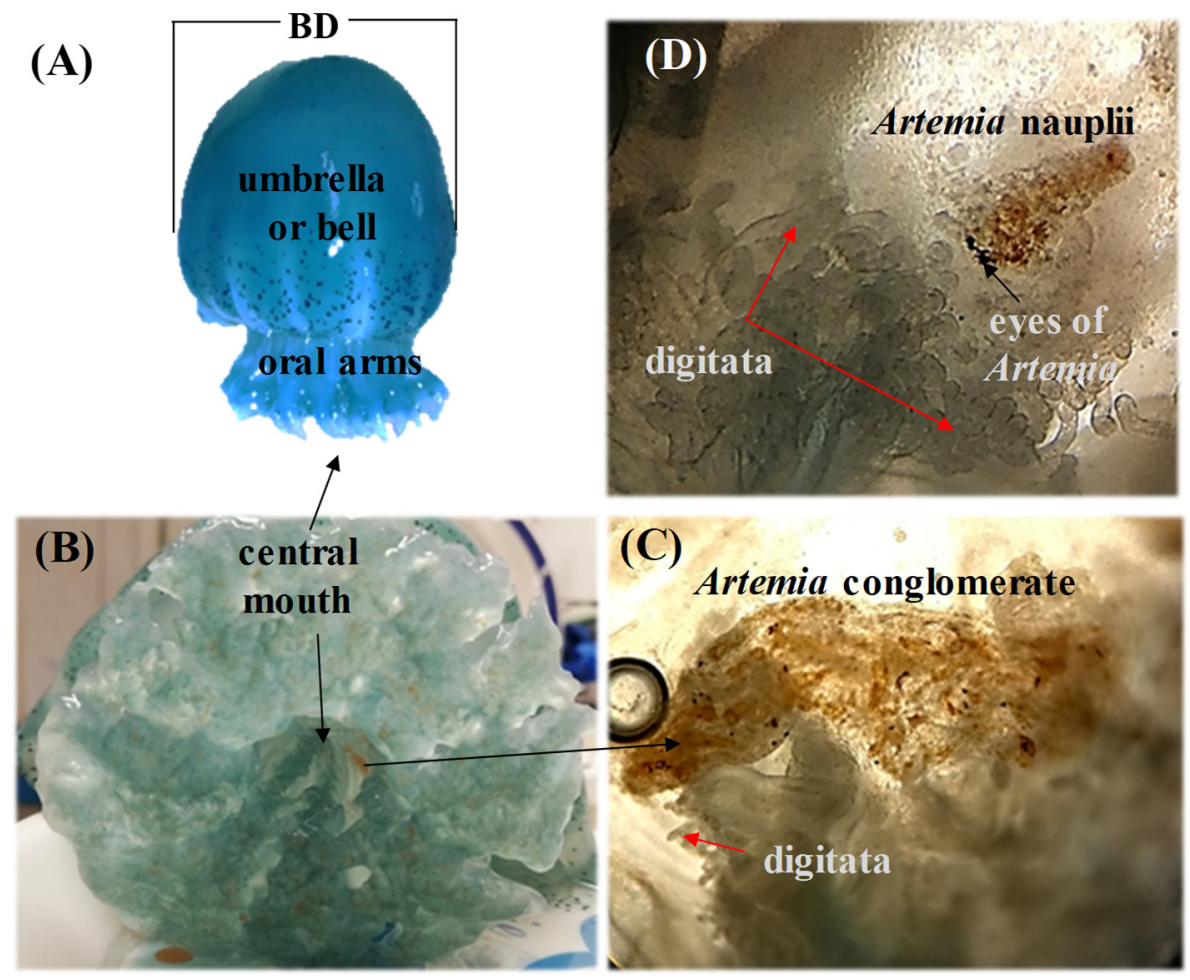

(C)

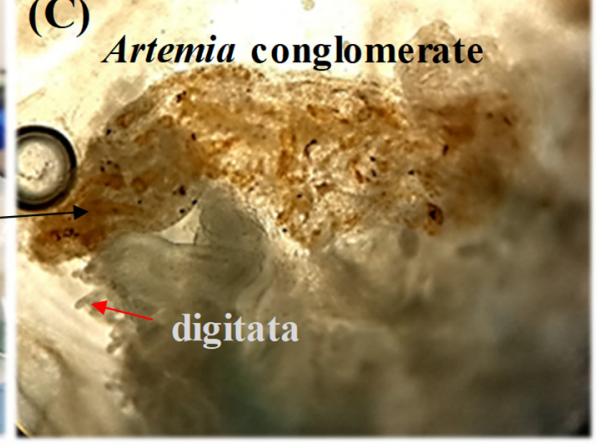

Figure 2. (A) Stomolophus sp. 2 showing the bell diameter (BD), umbrella or bell, manubrium (lower portion), oral arms in the manubrium, and its characteristic blue pigmentation. (B) Oral region where the medusae captures food with the digitata. (C) Various Artemia nauplii conglomerated in the digitata. (D) Artemia nauplii seemingly predigested.

Table 1. Feeding treatment, rates, and dates when essays were done.

\begin{tabular}{cccc}
\hline Date & Food Item & Items/7 L & Feeding Rate \\
\hline 09-13 Feb & Artemia franciscana nauplii & 65,000 & $9.29 / \mathrm{mL}$ \\
\hline 07-11 Mar & Cassostrea gigas “D” larvae & 65,000 & $9.29 / \mathrm{mL}$ \\
\hline 19-23 Mar & Totoaba macdonaldi fish eggs & 2400 & $0.34 / \mathrm{mL}$ \\
\hline
\end{tabular}

The number of prey items per treatment of Artemia nauplii and " $\mathrm{D}$ " mollusk larvae were chosen following Larson [31]. The diet of captive medusa often consists of Artemia spp. nauplii [44], which contains proteins and lipids to cover their feeding needs [45]. The feeding rates for Artemia nauplii and " $\mathrm{D}$ " larvae were 65,000/7 L. The concentration of fish eggs was subject to availability of induced spawning of adults at CREMES. We nevertheless made sure that enough eggs were available for the medusae $(0.34 / \mathrm{mL}$ compared to $0.05 / \mathrm{mL}$ egg in the wild [46]). After the cleaning process of the experimental tanks, the concentrations were set up to the designated rates. Pulsation rates of medusae caused when food items were provided were determined by direct observations and video recordings.

Due to the distinctive brownish-orange color and size of nauplii, we only described the feeding process of medusae fed Artemia nauplii. In contrast to the case of " $\mathrm{D}$ " larvae and fish eggs, the characteristic color of nauplii allowed its visualization, and facilitated a detailed description of how food was transported inside the medusae, both with the naked eye and under the microscope. 


\subsection{Mucus Samples}

As soon as medusae were placed back from the temporary containers into the essay tanks and were fed, they began producing mucus. Depending on time availability, between one and five samples of mucus were collected from the bottom using plastic Pasteur pipettes. These samples were easily collected because the mucus is denser and therefore settled below the sea water. The $20 \mathrm{~mL}$ samples were immediately observed under a Carl Zeiss Primo Star microscope (Oberkochen, Germany). Thorough analyses were performed, identifying and recording items found. In the case of nematocyst found in the mucus, a Marienfeld Neubauer camera (Lauda-Königshofen, Germany) was used with $100 \times$ augmentation.

\subsection{Reproduction}

We registered oocytes ca. $50 \%$ of the times that they were expelled and fertilized, found in mucus collected from the bottom of the containers, observed both in experimental $(70 \%)$ and controls (30\% of the containers). These reproductive cells were kept in isolation in crystal vases with low and constant aeration at $23{ }^{\circ} \mathrm{C}$. Microscope glass slides and fine plastic mesh $(500 \mu \mathrm{m})$ were placed inside the vases to allow planula larvae to settle and develop into polyps. We kept a micrographic register and measured size of oocytes, planula, and polyps using the software Adobe Photoshop CS extended version 13.1.2.

\subsection{Change in Bell Diameter}

The change in size of medusae was analyzed, comparing their initial and final bell diameter (BD). First, we evaluated possible differences in initial BD for all three treatments and the control to account for the possibility that initial size could have an effect in the change of $\mathrm{BD}$. We then computed the proportion of change in $\mathrm{BD}$ as:

$$
\mathrm{BD}=\frac{B D i-B D f}{B D i}
$$

where $B D i$ and $B D f$ are, respectively, the initial and final bell diameter of each medusae.

The resulting proportions $(\mathrm{X})$ were transformed using

$$
2(\operatorname{arcsine}[\sqrt{X}])
$$

prior to applying the Kruskal-Wallis test of equality of medians [47]. The same nonparametric test was used to analyze possible differences in initial size of medusae. As the null hypotheses of equal medians could not be rejected in either of the two analyses, no post-hoc test were further conducted.

\section{Results}

\subsection{Feeding Behavior}

For medusae fed Artemia nauplii, we found food (Figure 2B,C) in oral arms and scapulets (folds at the bases of the lobes of the manubrium) covered with mucus (Figure 3). During the transport of food items, we observed digitata covering the base of the inner oral arms throughout the mouth; it was here where we found food items conglomerated and adhered (Figure 2B,C). Once the jellyfish captured food items, there was a two-fold change in their activity: (1) increased pulsations of the umbrella, and (2) swimming in one direction, to random vertical swimming in the water column. Pulsation rates increased by an estimated $20 \%$ as determined by direct observations and video recordings. Food captured in the scapulets were fragmented into smaller particles (Figure 2D) and incorporated to adjacent pores (Figure 4D). Food was also conveyed through transport channels (CT) (Figure 3), driven by water flow to the mid-section of the central tube or esophagus, and from there to the gastrovascular cavity, where food accumulation was observed (Figure 5). Once in the gastric cavity, food was digested through the gastric filaments (Figure 5), and incorporated through the translucid umbrella radial channels, which took the same brownish-orange color as the food item (Artemia nauplii). 


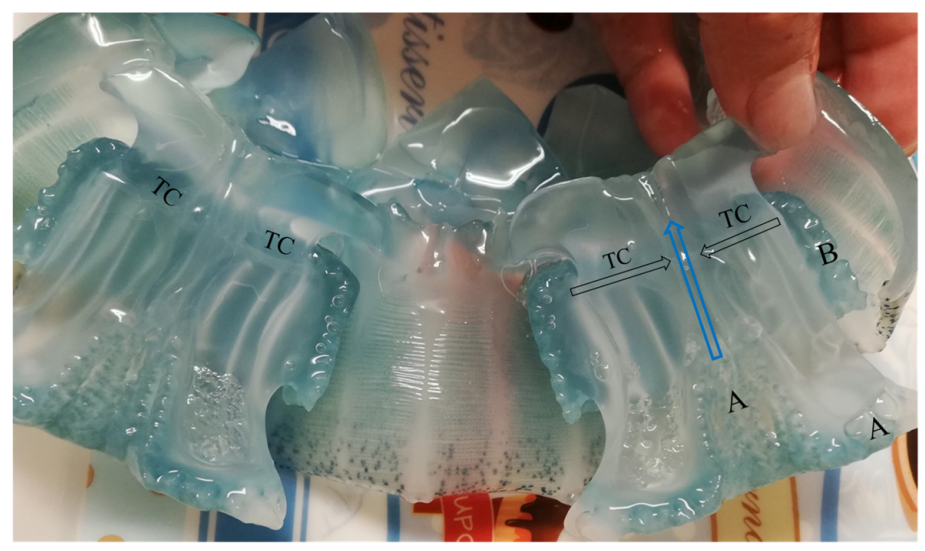

Figure 3. Longitudinal section of medusae showing the transport of food. A: location of digitata at the end of the oral arms and central tube of medusae; B: digitata in scapulets conducting food through the transport channels (TC).

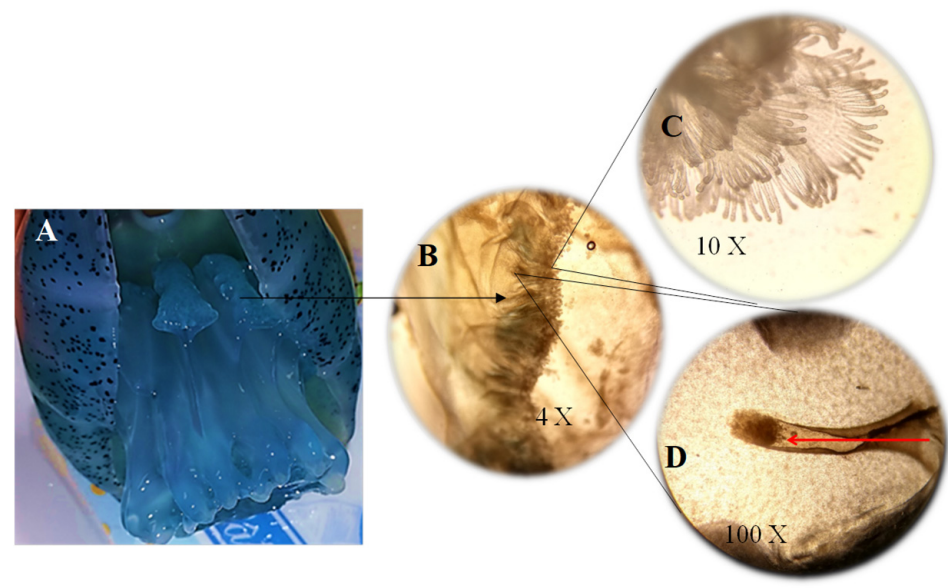

Figure 4. (A) Medusae showing scapulets; (B) Cross section of the scapulets (4×); (C) Digitata (10×); (D) Pore located in the digitata and indicated by the red arrow, the transport of particulate food $(100 \times)$.

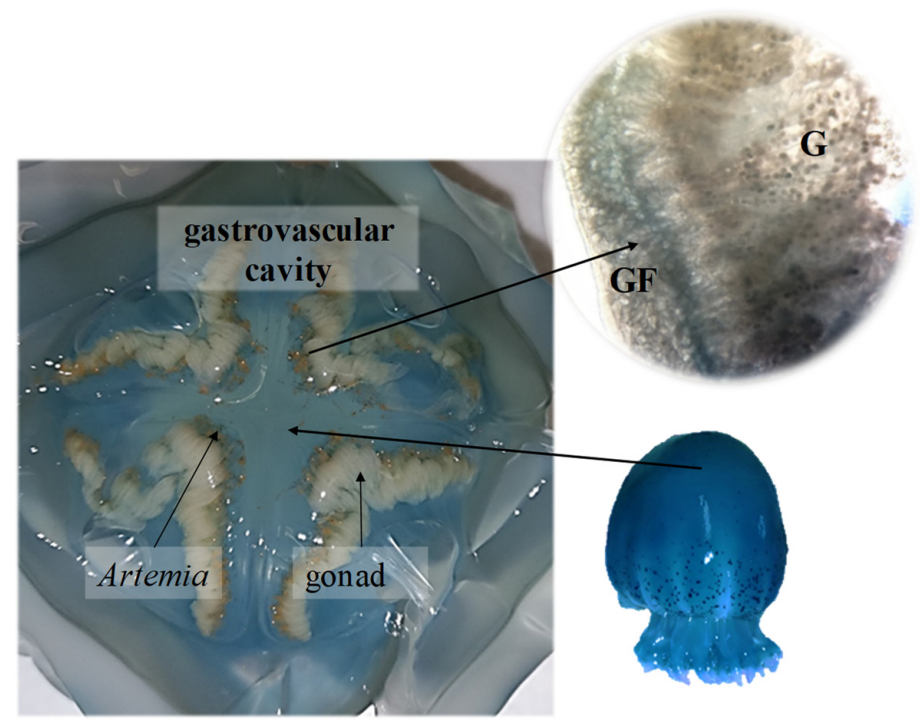

Figure 5. Cross-section of a Stomolophus sp. 2 umbrella showing the gastrovascular cavity. G: Female gonad with oocytes; GF: Gastric filaments. 


\subsection{Mucus Secretion}

After each water exchange, we evidenced expulsion of mucus and water with encapsulated or conglomerated food items. No observable differences were detected in mucus production related to food items. Observation under the microscope enabled us to identify food and gastric structures (Figure 6A). In the control medusae, we observed that even when under starving condition, they clearly produced the same viscous liquid and also contained oocytes, gastric filaments, and food scraps (Figure 6B).

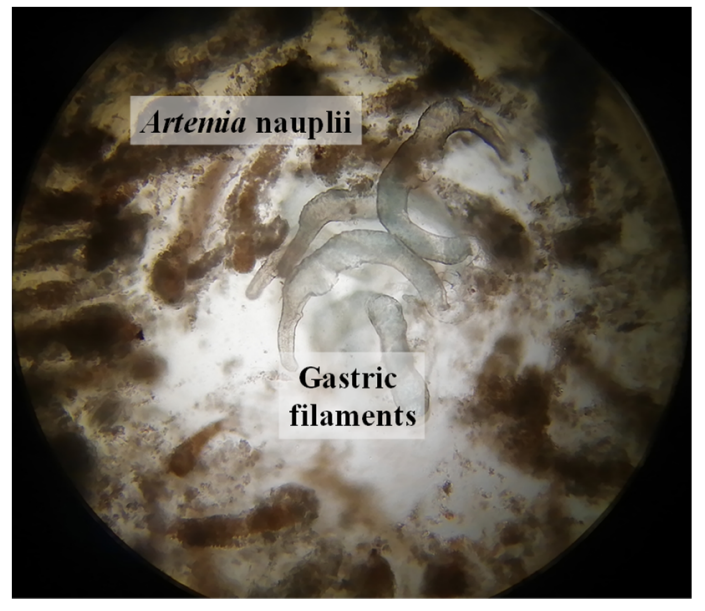

(A)

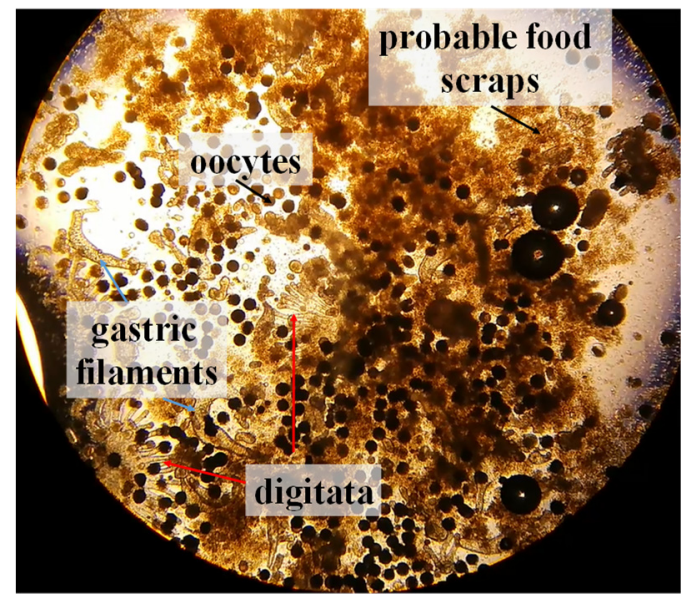

(B)

Figure 6. Structures found in the mucus expelled by S. sp. 2. (A) Food and gastric filaments. (B) Mucus expelled by a three-day starving medusa showing oocytes, gastric filaments, and digitata.

Similarly observed in the mucus were nematocyst-like structures (Figure 7), which were previously reported for Stomolophus [48].

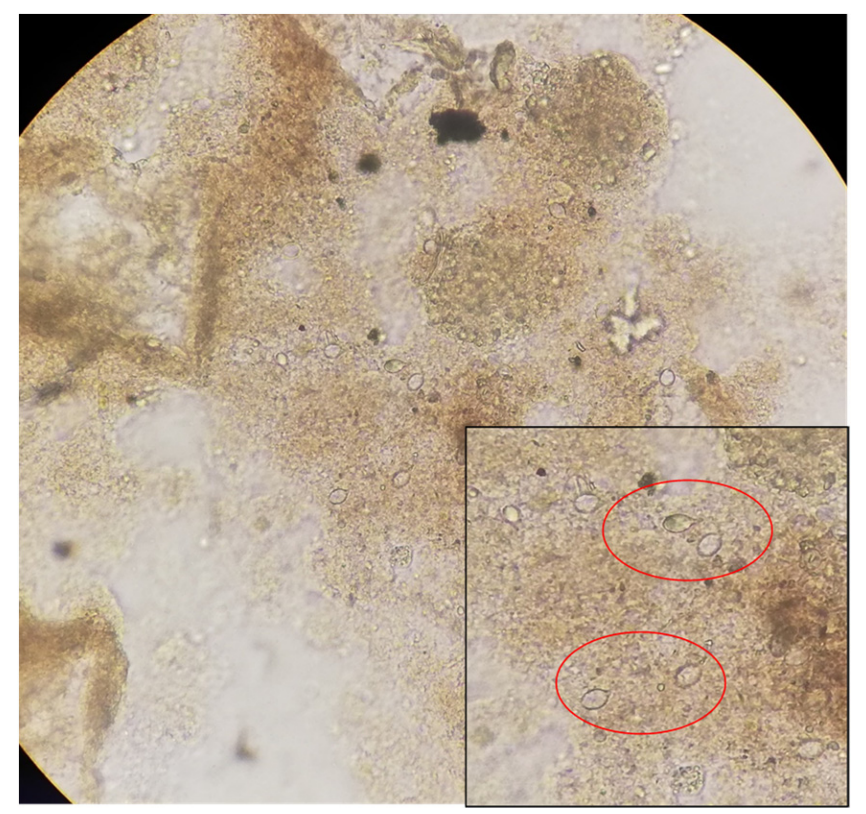

Figure 7. Probable nematocyst found in the mucus expelled by Stomolophus. sp. 2, observed using a Neubauer camera at a $100 \times$ magnification.

\subsection{Reproduction}

During the course of the present work, oocytes were observed in some of the experimental containers (see below); in such cases, the water temperature ranged from 21.6 to 
23. ${ }^{\circ} \mathrm{C}$. The presence of oocytes in experimental tanks (six replicates and three controls) varied only slightly with the food treatment: Artemia nauplii, 5 out of $9(56 \%)$; "D" larvae, 4 out of 9 (44\%); and fish eggs 4 out of 9 (44\%) containers. Approximately (estimated by the first two authors) 80 to $90 \%$ of observed oocytes were undergoing cleavage. In the same proportion of observed oocytes per container, expelled digitata structures were also found in the mucus/water samples (Figure 8A). Planula larvae were also found in the water column of the experimental systems, and in a few of them (10\%), polyps were also observed (Figure 8B). Oocytes collected which were in good shape were isolated in glass vases, and their development was observed (Figure 8B).

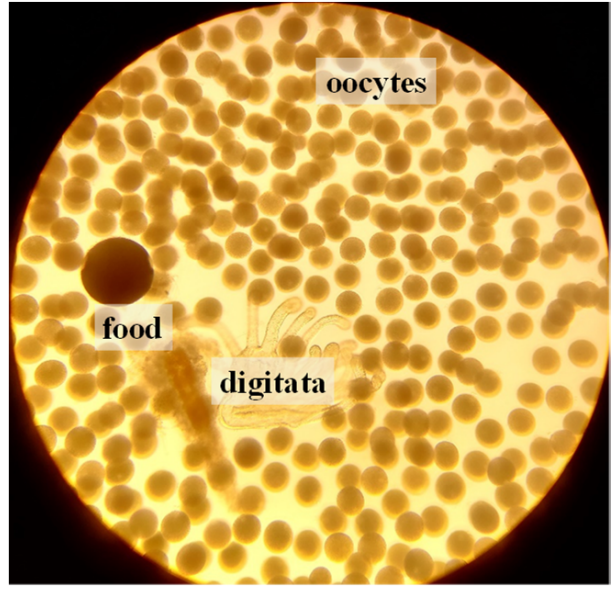

(A)

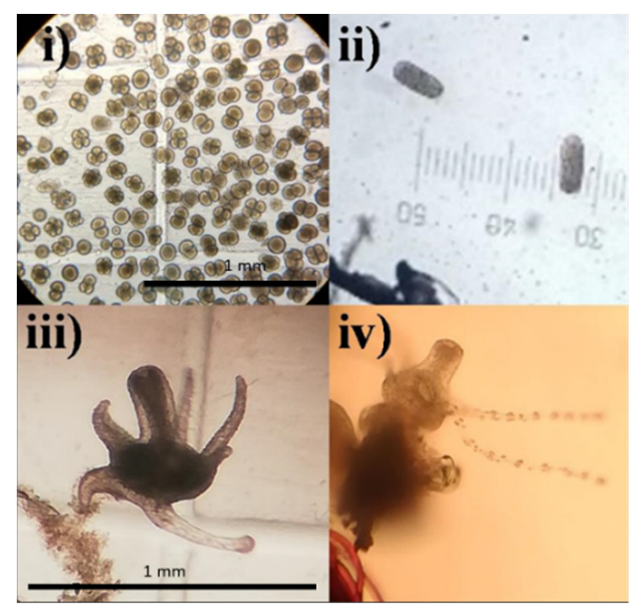

(B)

Figure 8. Structures found in the mucus expelled by S. sp. 2. (A) Oocytes expelled by a fed medusa. (B) i: Developing oocytes measuring 99 to $144 \mu \mathrm{m}$ in diameter; ii: planula measuring $150 \mu \mathrm{m}$ in length; iii: polyps measuring $430 \mu \mathrm{m}$ in length with retracted tentacles; iv: $210 \mu \mathrm{m}$ polyp with extended tentacles.

Oocytes, planula, and polyps were also observed in the control containers, although less frequently: 2 out of 9 containers or $22.2 \%$ contained either of all of those three life stages. In the control group, majority of oocytes deteriorated and did not develop. Other feeding structures were also found in these cases (Figure 6B).

\subsection{Change in Bell Diameter}

During the experimental periods, a median BD reduction of $8.5 \mathrm{~mm}(n=12), 9.5 \mathrm{~mm}$ $(n=12), 10 \mathrm{~mm}(n=12)$, and $9.25 \mathrm{~mm}(n=12)$ were observed in individuals fed Artemia nauplii, " $\mathrm{D}$ " larvae, fish eggs, and control $(n=16)$, respectively. There were no significant differences neither in the median initial size $(H=0.71, P=0.87)$, nor the proportion of reduction in size $(H=2.11, P=0.54)$ between either of the four treatments (Figure 9).

Small lacerations in the umbrella, and damage to the oral arms were also observed. These medusae showed a decrease or absence of digitate structures, which were found in the mucus samples. 


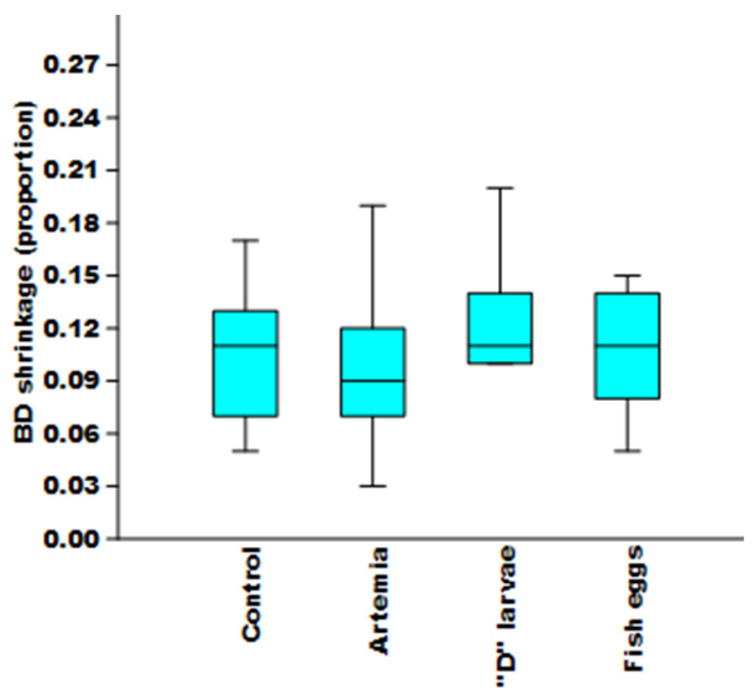

Figure 9. Reduction (proportional to initial size) in bell diameter (BD) of Stomolophus sp. 2 at the end of the bioassays.

\section{Discussion}

The relatively recent frequency of jellyfish blooms worldwide can significantly affect commercial fisheries; it is therefore essential to study all issues related to them. In the case of Mexico, Stomolophus spp. [49] demands biological and ecological research to better understand the role of jellyfish species in ecosystems and provide useful information for planning adequate management actions. Through controlled experiments in S. sp. 2 specimens, the effect of different food items and stressors were observed, noting responses regarding: (1) feeding behavior, (2) secretion of mucus, and (3) decrease in bell diameter (BD) of medusae.

\subsection{Feeding Behavior}

During feeding, food items were incorporated into two structures: oral arms using multiple mouths with accessory structures (digitata), and scapulets through channels transporting food to the gastric chamber. This type of feeding was documented for other Scyphozoan medusa (L. lucerna and N. nomurai $[25,28,50,51]$ ), which have the same feeding structures observed in $S$. sp. 2 . The feeding process begins when prey items are captured through negative pressure by a water flux produced by the medusae; the amount of prey encountered varies depending on the siphoned water volume [50]. As we used a relatively small water volume (7 L) in the experimental containers, this may have facilitated the encounter rates of medusae and food. Medusae captured prey items and transported them to the gastric chamber. In the present work, we observed that the pulse rate of the umbrella increased while the medusae was feeding. Despite the small water volume, we were able to observe that the direction of swimming changed to an up-down behavior once prey items were detected, most likely to maximize encounter rates. This behavior was observed in A. aurita and is regarded as an advantage during food search $[5,50,52]$.

The roles of mucus and digitata are to compact and direct food to the mouth, which is later transported through the esophagus into the gastric chamber to be enzymatically digested [5,27]. Using much larger water volume in N. nomurai, it takes from 10 to $20 \mathrm{~min}$ to retain food with the oral arms, scapulets, and manubrium, whereas in S. sp. 2, it took only seconds to min. Such difference might be related to species-specific anatomic and feeding strategies $[28,50]$. While $N$. nomurai ingests prey through the pores in the oral arms, $S$. sp. 2 begins the ingestion process in the central mouth. This could be regarded as an adaptive feature to increase ingestion efficiency when food is available in the environment. However, digestion, regarded here as the vanishing of food items inside the umbrella, can 
be considered a slow process compared to other species. In $N$. nomurai, this takes only $1 \mathrm{~h}$ and $20 \mathrm{~min}$, while in S. sp. 2, food remained in the umbrella channels after $12 \mathrm{~h}$ of ingestion.

\subsection{Mucus Secretion}

Our results and a careful analysis of the scientific literature, indicate the great importance of mucus for jellyfish species. After observing the items found in the mucus of S. sp. 2, we concluded that the release of mucus had three purposes: food capture, defense, and to facilitate sexual reproduction. Mucus production significantly facilitated jellyfish to capture prey because it forms lumps or conglomerates. Studies of other medusae reported that mucus promotes food transportation through the esophagus to the gastric pockets, even when prey items were small [5,25,53-55]. In our work, mucus production could result from the expulsion of food from the mouth due to manipulation-induced stress, as has been described for other species [5].

Mucus production could be a protective mechanism as a reaction to manipulation $[31,32,35]$ and serves as a defense against potential predators, judging by the significant number of nematocysts found in it $[31,32,35,36,56]$, as observed in the present work. The mucus in Cnidaria contains components for self-defense [32,34,36,57,58]. When A coerulea is stressed by environmental cues, it reacts in the same fashion as observed after manipulation [32].

Oocytes were found in the mucus of $S$. sp. 2, which suggests that it is also important in sexual reproduction, as previously reported for $P$. noctiluca. For this species, mucus increases the buoyancy of eggs and the likelihood of fertilization by maintaining strings of eggs in the water column [37,59]. It should be cautioned that both P. noctiluca and S. sp. 2 are broadcast spawners, but the former is holoplanktonic, i.e., it does not have a benthic stage [60]. This strategy was not evident in the case of $S$. sp. 2 under captivity. In the present study, the highest number of oocytes were found in mucus collected from the bottom of the containers; this might not be a natural behavior displayed by S. sp. 2. Sperm was not observed even when it had to be expelled to fertilize the oocytes. Calder [18] described the life cycle of $S$. meleagris and pointed out that the fertilized egg produces a planula larva which swims in the water column for 2 to 5 days before settling in the bottom.

The mucus remained near the water surface for a few min after release, then circulated in the water column, ending on the bottom of the containers together with food and other structures. It was reported that the mucus in A. aurita and Carybdea rastonii functioned as a "conveyor", transporting organic matter to the sea bottom [55].

We hypothesize here that gamete release can be due to either of two factors. First, the intensity with which mucus is produced, based on findings of other internal structures such as digitata and gastric filaments. Alternatively, because of the starving conditions of medusae. Gametes were released, which resulted in fertilization; posterior formation of planula, observed in this work; and polyps attached to different substrates, such as glass slides and pieces of plastic net placed in the containers. This was observed in other species of medusae where the allotment of energy depended on food availability [37,61]. Sexual reproduction to ultimately form polyps can be an adaptive behavior. It is known that the benthic stage of Scyphozoans regulates the abundance of the medusoid stage because polyps are capable of surviving and asexually reproducing for several years [18,20,43].

\subsection{Size Reduction of Jellyfishes}

Shrinking may be a transitional resting stage while the environment improves $[37,62]$ which might be an adaptive behavior; when food is scarce, energy is spent in reproduction and offspring survival at the cost of not forming or even losing individual biomass $[37,61,63]$. For example, it was reported that $P$. noctiluca, a holoplanktonic jellyfish, released gametes over a 28-day starving period while losing body size [37].

Based on findings of the present work, we believe that the decrease in BD of $S$. sp. 2 resulted after the expulsion of feeding structures, the constant production of aquose mucus [25,36], and reproductive events. Brewer [64] suggested that medusae display two growth phases. In the first phase, they show an exponential growth; and in the second, 
the rate declined sharply and senesced. During the second, senescing phase, medusae lost structures. First, tentacles; followed by oral folds; and lastly, gonads, after which they die.

Like most fast-growing species, S. sp. 2 is quite susceptible to food availability; after $24 \mathrm{~h}$ of starving, individuals began to shrink. In Ctenophora, a 19\% to 63\% reduction of metabolic rate after $24 \mathrm{~h}$ of starvation was observed [65]. In the present work, prey items were offered separately, which may have not supplied enough nutrients to grow or maintain their size. In the wild, these medusae have access to a wide diversity of prey: fish eggs, copepods, bivalve larvae, gastropods, and Cirripedia [66,67], which together comprise a diet rich in protein and lipids to allow growth and gonad development $[66,68]$. Food availability was related to size regulation in A. aurita and P. noctiluca, as they shrank when food offered was not sufficient to fulfill their growth requirements $[24,44,61,63]$.

Reduction in BD was not significantly different in medusae fed fish eggs and " $\mathrm{D}$ " larvae or Artemia nauplii. Often, Artemia nauplii are fed to medusae in laboratory studies because they are easy to cultivate and provide nutrients for the first growth stages of many species $[44,69,70]$. Based on our observations, we believe that the reduction of BD of S. sp. 2 fed Artemia was not due to a reduced medusae capture efficiency. As soon as Artemia contacted the mucus and digitata, they remained still, similar to what occurs with $N$. nomurai [28]. The reason why medusae decreased in size in either food treatment seems to be related to constant production of gametes, mucus, and loss of feeding structures. Therefore, we pose that stressed medusae reduced feeding rate and channeled energy to sexual reproduction, i.e., released gametes without somatic growth, as was observed in other species in response to low food availability [61,63]. It should be noted that mucus production in cnidarians results in release of organic matter which contains proteins (mucin), lipids, carbohydrates, and various organic elements, such as dissolved nitrogen, free amino acids, and organic phosphorus [71,72]. The production of mucus is species- and weight-specific [72], so it should be surprising that its secretion produced the shrinking of S. sp. 2.

\subsection{Feeding Structures in Mucus}

To our knowledge, the feeding structures found in the mucus, gastric filaments and digitata, had not previously been reported for adult Stomolophus sp. 2. It was documented that, prior to death, medusae decay until shape changes, losing tissues and shortening oral arms and tentacles $[64,69,73]$. The latter was observed in the present work in the umbrella and reduction of digitata, feeding structures associated to oral arms used to capture food [5,74]. Shrinking of tentacles when food was scarce was related to autophagia [29,73] as an adaptation to reduce body mass under unfavorable metabolic and environmental conditions, allowing medusae to adapt to scarce food [29,32,62,75,76]. However, we believe that under such conditions, losing or reducing size of digitata can increase damage and reduce survival. These structures aid in capturing food, and shrinking would decrease medusae feeding ability, thereby precluding growth, or even reducing size. This was observed for L. lucerna, which, under high temperature and low food, contracted their tentacles and reduced size and movement, which impeded food intake, ultimately leading to death [74]. This phenomenon was also observed in Cassiopea spp. which, when subjected to low temperatures, decreased body mass, and lost tentacles and the ability to transfer captured food to the mouth [77].

We argue that such a phenomenon is of key importance in the wild. If gregarious $S$. sp. 2 cannot find food in a relatively short period of time, they decrease or lose their ability to eat. If food is available afterwards, they will not be able to ingest it, which will lead to potentially massive deaths. S. sp. 2 are strong jet-propulsion swimmers $[35,51]$, selective feeders [31,67], and fast growers [78]. The high local variability in abundance of this species is most likely related to their need to move constantly in search for food. Finally, the production of mucus seems to be a key factor affecting the BD of $S$. sp. 2. The constant production of mucus followed by autolysis under stress, as in the cases of $A$. coerulea and $S$. meleagris [32,79], can be a factor determining the high variability of jellyfish in general. 


\section{Conclusions}

For adult Stomolophus sp. 2, we provided the first detailed descriptions of feeding structures and how they function to capture and process food items. Digitata (finger-like projections covering the inner oral arms through the mouth) adheres food, and scapulets fragment them into smaller particles, which are incorporated into adjacent pores. Driven by water flow, food passes through transport channels to the esophagus and the gastric chamber and is digested through gastric filaments.

Mucus production after manipulation of medusae increased the pulse rate of the umbrella, and a change in the swimming direction might result in a high capture efficiency of prey. This allows medusae to ingest large amounts of food in short time periods, provided that the prey offered or found in the wild satisfies their needs to grow and remain alive.

The function of mucus in S. sp. 2 seems especially important in feeding by facilitating capture and packing of prey. Mucus also appears to be important as a defense mechanism and for sexual reproduction of this species; further studies are needed in this respect.

In S. sp. 2, the role of mucus in sexual reproduction might improve the likelihood of a successful population, because fertilized oocytes transform into planulae, which then settle to produce benthic polyps that are more resistant to environmental stress than the medusae stage $[18,79]$.

Author Contributions: Conceptualization, A.V.C.-P. and M.Á.C.-M.; methodology, A.V.C.-P., L.C.G.-S., D.R.-F. and M.Á.C.-M.; validation, L.M.D.-T., M.L.U.-B. and M.Á.C.-M.; formal analysis, A.V.C.-P., M.Á.C.-M. and L.C.G.-S.; investigation, A.V.C.-P., L.C.G.-S., L.M.D.-T., M.Á.C.-M. and M.L.U.-B.; writing-original draft preparation, A.V.C.-P., L.C.G.-S. and M.Á.C.-M.; writing-review and editing, A.V.C.-P., L.C.G.-S., M.Á.C.-M., L.M.D.-T., M.L.U.-B. and D.R.-F.; visualization, A.V.C.-P. and L.C.G.-S.; supervision, M.Á.C.-M. and L.M.D.-T.; project administration, M.Á.C.-M. and L.M.D.-T.; funding acquisition, M.Á.C.-M. and M.L.U.-B. All authors have read and agreed to the published version of the manuscript.

Funding: Partial financial support was received by Instituto de Acuacultura del Estado de Sonora (contract number CE-IAES-002-2018-ITSON). This support included purchasing of materials and hiring of one technician to aid in the essays.

Institutional Review Board Statement: Collection of jellyfish was conducted on board a commercial fishing boat with the corresponding official fishing permit 126047998021 . The sample size was kept at a minimum and no harm was produced to the natural biomass or the fishers.

Data Availability Statement: Data resulting of the present work can be obtained from the first author.

Acknowledgments: Instituto de Acuacultura del Estado de Sonora (IAES) provided partial financial aid and experimental facilities. Instituto Tecnológico de Sonora in Ciudad Obregón administrated the funds. Edgar Alcántara from Centro de Investigaciones Biológicas del Noroeste-Guaymas Applied Ecology Fisheries lab drafted the figures. Personnel from Instituto Nacional de Pesca y Acuacultura in Guaymas aided in gathering samples of jellyfish. Fishers of Las Guásimas Bay, Sonora, allowed collecting jellyfish on board their artisanal fishing boats. Tracey Mangin and Lucas Brotz improved the grammar and syntax of this manuscript.

Conflicts of Interest: The authors declare no conflict of interest.

\section{References}

1. Mills, C.E. Jellyfish blooms: Are populations increasing globally in response to changing ocean conditions? Hydrobiologia 2001, 451, 55-68. [CrossRef]

2. Brotz, L.; Schiariti, A.; López-Martínez, J.; Álvarez-Tello, J.; Peggy Hsieh, Y.H.; Jones, R.P.; Quiñones, J.; Dong, Z.; Morandini, A.C.; Preciado, M.; et al. Jellyfish fisheries in the Americas: Origin, state of the art, and perspectives on new fishing grounds. Rev. Fish Biol. Fish. 2017, 27, 1-29. [CrossRef]

3. Brotz, L.; Pauly, D. Jellyfish populations in the Mediterranean Sea. Acta Adriat. 2012, 53, 211-230.

4. Lynam, C.; Gibbons, M.; Axelsen, B.E.; Sparks, C.; Coetzee, J.; Heywood, B.; Brierley, A. Jellyfish overtake fish in a heavily fished ecosystem. Curr. Biol. 2006, 16, 492-493. [CrossRef] [PubMed]

5. Arai, M.N. A Functional Biology of Scyphozoa; Chapman \& Hall: London, UK; Weinheim, Germany; New York, NY, USA; Tokyo, Japan; Melbourne, Australia; Madras, India, 1997; p. 316. 
6. Duarte, C.M.; Pitt, K.; Lucas, C.; Purcell, J.E.; Uye, S.-I.; Robinson, K.; Brotz, L.; Decker, M.B.; Sutherland, K.; Malej, A.; et al. Is global ocean sprawl a cause of jellyfish blooms? Front. Ecol. Environ. 2013, 11, 91-97. [CrossRef]

7. Condon, R.H.; Duarte, C.M.; Pitt, K.A.; Robinson, K.L.; Lucas, C.H.; Sutherland, K.R.; Mianzan, H.W.; Bogeberg, M.; Purcell, J.E.; Decker, M.B.; et al. Recurrent jellyfish blooms are a consequence of global oscillations. Proc. Natl. Acad. Sci. USA 2013, 110, 1000-1005. [CrossRef]

8. Xian, W.; Kang, B.; Liu, R. Jellyfish Blooms in the Yangtze Estuary. Science 2005, 307, 41. [CrossRef]

9. Amorim, K.; Mattmüller, R.; Algueró-Muñiz, M.; Meunier, C.; Alvarez-Fernandez, S.; Boersma, M.; Morais, P.; Teodósio Chícharo, M. Winter river discharge may affect summer estuarine jellyfish blooms. Mar. Ecol. Prog. Ser. 2018, 591, 253-265. [CrossRef]

10. Brodeur, R.; Decker, M.; Ciannelli, L.; Purcell, J.; Bond, N.; Stabeno, P.; Acuna, E.; Hunt, G. Rise and fall of jellyfish in the eastern Bering Sea in relation to climate regime shifts. Prog. Oceanogr. 2008, 77, 103-111. [CrossRef]

11. Purcell, J. Climate effects on formation of jellyfish and ctenophore blooms: A review. J. Mar. Biol. Assoc. U. K. 2005, 85, 461-476. [CrossRef]

12. Purcell, J. Jellyfish and Ctenophore Blooms Coincide with Human Proliferations and Environmental Perturbations. Annu. Rev. Mar. Sci. 2012, 4, 209-235. [CrossRef] [PubMed]

13. Suchman, C.; Brodeur, R.; Daly, E.; Emmett, R. Large medusae in surface waters of the Northern California Current: Variability in relation to environmental conditions. Hydrobiologia 2012, 690, 113-125. [CrossRef]

14. Boero, F.; Brotz, L.; Gibbons, M.; Piraino, S.; Zampardi, S. Impacts and effects of ocean warming on jellyfish. In Explaining Ocean Warming: Causes, Scale, Effects and Consequences; Laffoley, D., Baxter, J.M., Eds.; IUCN: Gland, Switzerland, 2016 ; pp. $213-237$.

15. Moller, H. Reduction of a Larval Herring Population by Jellyfish Predator. Science 1984, 224, 621-622. [CrossRef] [PubMed]

16. Purcell, J. Predation on fish eggs and larvae by pelagic cnidarians and ctenophores. Bull. Mar. Sci. 1985, 37, 739-755.

17. Purcell, J. Extension of methods for jellyfish and ctenophore trophic ecology to large-scale research. Hydrobiologia 2009, 616, 23-50. [CrossRef]

18. Calder, D.R. Life History of the cannonball jellyfish, Stomolophus meleagris L. Agassiz, 1860 (Scyphozoa, Rhizostomida). Biol. Bull. 1982, 162, 149-162. [CrossRef]

19. Helm, R.R. Evolution and development of scyphozoan jellyfish. Biol. Rev. Camb. Philos. Soc. 2018, 93, 1228-1250. [CrossRef]

20. Lucas, C.; Graham, W.; Widmer, C. Jellyfish Life histories: Role of polyps in forming and maintaining scyphomedusa populations. Adv. Mar. Biol. 2012, 63, 133-196.

21. Kikinger, R. Cotylorhiza tuberculata (Cnidaria: Scyphozoa)—Life History of a Stationary Population. Mar. Ecol. 2008, 13, 333-362. [CrossRef]

22. Phillips, P.J.; Burke, W.D.; Keener, E.J. Observations on the Trophic Significance of Jellyfishes in Mississippi Sound with Quantitative Data on the Associative Behavior of Small Fishes with Medusae. Trans. Am. Fish. Soc. 1969, 98, 703-712. [CrossRef]

23. Larson, R.J. Feeding in Coronate medusae (class Scyphoza, order Coronatae). Mar. Behav. Physiol. 1979, 6, 123-129. [CrossRef]

24. Larson, R.J. A Note on the Feeding, Growth, and Reproduction of the Epipelagic Scyphomedusa Pelagia noctiluca (Forskål). Biol. Oceanogr. 1987, 4, 447-454.

25. Nagata, R.M.; Morandini, A.C. Diet, prey selection, and individual feeding rates of the jellyfish Lychnorhiza lucerna (Scyphozoa, Rhizostomeae). Mar. Biol. 2018, 165, 1-17. [CrossRef]

26. Hansson, L.J. Capture and digestion of the scyphozoan jellyfish Aurelia aurita by Cyanea capillata and prey response to predator contact. J. Plankton Res. 1997, 19, 195-208. [CrossRef]

27. Heeger, T.; Möller, H. Ultrastructural observations on prey capture and digestion in the scyphomedusa Aurelia aurita. Mar. Biol. 1987, 96, 391-400. [CrossRef]

28. Lee, H.E.; Yoon, W.D.; Lim, D. Description of feeding apparatus and mechanism in Nemopilema nomurai Kishinouye (Scyphozoa: Rhizostomeae). Ocean Sci. J. 2008, 43, 61-65. [CrossRef]

29. Fujita, S.; Kuranaga, E.; Nakajima, Y.-I. Cell proliferation controls body size growth, tentacle morphogenesis, and regeneration in hydrozoan jellyfish Cladonema pacificum. Peer] 2019, 7, e7579. [CrossRef]

30. Nagata, R.; Morandini, A.; Colin, S.; Migotto, A.; Costello, J. Transitions in morphologies, fluid regimes, and feeding mechanisms during development of the medusa Lychnorhiza lucerna. Mar. Ecol. Prog. Ser. 2016, 557, 145-159. [CrossRef]

31. Larson, R.J. Diet, prey selection and daily ration of Stomolophus meleagris, a filter-feeding scyphomedusa from the NE Gulf of Mexico. Estuar. Coast. Shelf Sci. 1991, 32, 511-525. [CrossRef]

32. Liu, W.; Mo, F.; Jiang, G.; Liang, H.; Ma, C.; Li, T.; Zhang, L.; Xiong, L.; Mariottini, G.; Zhang, J.; et al. Stress-Induced Mucus Secretion and Its Composition by a Combination of Proteomics and Metabolomics of the Jellyfish Aurelia coerulea. Mar. Drugs 2018, 16, 341. [CrossRef]

33. Patwa, A.; Thiéry, A.; Fabien, L.; Lilley, M.; Claire, B.; Bramard, J.-F.; Bottero, J.-Y.; Barthélémy, P. Accumulation of nanoparticles in "jellyfish" mucus: A bio-inspired route to decontamination of nano-waste. Sci. Rep. 2015, 5, 11387. [CrossRef]

34. Bakshani, C.R.; Morales-Garcia, A.L.; Althaus, M.; Wilcox, M.D.; Pearson, J.P.; Bythell, J.C.; Burgess, J.G. Evolutionary conservation of the antimicrobial function of mucus: A first defence against infection. NPJ Biofilms Microbiomes 2018, 4, 14. [CrossRef]

35. Shanks, A.; Graham, W.M. Chemical defense in a scyphomedusa. Mar. Ecol.-Prog. Ser. 1988, 45, 81-86. [CrossRef]

36. Lewis Ames, C.; Klompen, A.; Badhiwala, K.; Muffett, K.; Reft, A.; Kumar, M.; Janssen, J.; Schultzhaus, J.; Field, L.; Muroski, M.; et al. Cassiosomes are stinging-cell structures in the mucus of the upside-down jellyfish Cassiopea xamachana. Commun. Biol. 2020, 3, 1-15. 
37. Lilley, M.; Elineau, A.; Ferraris, M.; Thiéry, A.; Stemmann, L.; Gorsky, G.; Fabien, L. Individual shrinking to enhance population survival: Quantifying the reproductive and metabolic expenditures of a starving jellyfish, Pelagia noctiluca. J. Plankton Res. 2014, 36, 1585-1597. [CrossRef]

38. Kos Kramar, M.; Tinta, T.; Lucic, D.; Malej, A.; Turk, V. Bacteria associated with moon jellyfish during bloom and post-bloom periods in the Gulf of Trieste (northern Adriatic). PLoS ONE 2019, 14, e0198056. [CrossRef] [PubMed]

39. Iliff, S.M.; Wilczek, E.R.; Harris, R.J.; Bouldin, R.; Stoner, E.W. Evidence of microplastics from benthic jellyfish (Cassiopea xamachana) in Florida estuaries. Mar. Pollut. Bull. 2020, 159, 111521. [CrossRef] [PubMed]

40. Gómez-Daglio, L.; Dawson, M. Species richness of jellyfishes (Scyphozoa: Discomedusae) in the Tropical Eastern Pacific: Missed taxa, molecules, and morphology match in a biodiversity hotspot. Invertebr. Syst. 2017, 31, 635-663. [CrossRef]

41. Carvalho Saucedo, L.; Martinez, J.; Garcia Dominguez, F.; Rodríguez-Jaramillo, M.; Padilla Serrato, J. Biología reproductiva de la medusa bola de cañón Stomolophus meleagris en la laguna Las Guásimas, Sonora, México. Hidrobiológica 2011, $21,77-88$.

42. Purcell, J.E.; Fuentes, V.; Atienza, D.; Tilves, U.; Astorga, D.; Kawahara, M.; Hays, G.C. Use of respiration rates of scyphozoan jellyfish to estimate their effects on the food web. Hydrobiologia 2010, 645, 135-152. [CrossRef]

43. Lechable, M.; Jan, A.; Weissbourd, B.; Uveira, J.; Gissat, L.; Collet, S.; Gilletta, L.; Chevalier, S.; Leclère, L.; Peron, S.; et al. An improved whole life cycle culture protocol for the hydrozoan genetic model Clytia hemisphaerica. Biol. Open 2020, 9, 1-13. [CrossRef]

44. You, K.; Ma, C.; Gao, H.; Li, F.; Zhang, M.; Qiu, Y.; Wang, B. Research on the jellyfish (Rhopilema esculentum Kishinouye) and associated aquaculture techniques in China: Current status. Aquac. Int. 2007, 15, 479-488. [CrossRef]

45. Guevara, M.; Lodeiros, C. Composición bioquímica de nauplios y metanauplios de Artemia sp. (Crustacea, Anostraca) proveniente de la salina artificial de Araya, nororiente de Venezuela. Cienc. Mar. 2003, 29, 655-663. [CrossRef]

46. Hernandez-Nava, M.F.; Alvarez-Borrego, S. Zooplankton in a whale shark (Rhincodon typus) feeding area of Bahía de los Angeles (Gulf of California). Hidrobiológica 2013, 23, 198-208.

47. Sokal, R.; Rohlf, J.F. Biometry: The Principles and Practice of Statistics in Biological Research, 3rd ed.; W.H. Freeman: New, York, NY, USA, 1995.

48. Calder, D.R. Nematocysts of stages in the life cycle of Stomolophus meleagris, with keys to scyphistomae and ephyrae of western Atlantic Scyphozoa. Can. J. Zool. 1983, 61, 1185-1192. [CrossRef]

49. López-Martínez, J.; Álvarez-Tello, J. The jellyfish fishery in Mexico. Agric. Sci. 2013, 4, 57-61. [CrossRef]

50. Bezio, N.; Costello, J.H.; Perry, E.; Colin, S. Effects of capture surface morphology on feeding success of scyphomedusae: A comparative study. Mar. Ecol. Prog. Ser. 2018, 596, 83-93. [CrossRef]

51. Costello, J.H.; Colin, S.P. Flow and feeding by swimming scyphomedusae. Mar. Biol. 1995, 124, 399-406. [CrossRef]

52. Bailey, K.M.; Batty, R.S. Laboratory study of predation by Aurelia aurita on larvae of cod, flounder, plaice and herring: Development and vulnerability to capture. Mar. Biol. 1984, 83, 287-291. [CrossRef]

53. Basso, L.; Rizzo, L.; Piraino, S.; Stabili, L. Metabolic diversity of microbial community associated with Rhizostoma pulmo (Scyphozoa: Rhizostomeae). J. Mar. Microbiol. 2017, 1, 5-8.

54. Basso, L.; Rizzo, L.; Marzano, M.; Intranuovo, M.; Fosso, B.; Pesole, G.; Piraino, S.; Stabili, L. Jellyfish summer outbreaks as bacterial vectors and potential hazards for marine animals and humans' health? The case of Rhizostoma pulmo (Scyphozoa, Cnidaria). Sci. Total Environ. 2019, 692, 305-318. [CrossRef] [PubMed]

55. Hanaoka, K.I.; Ohno, H.; Wada, N.; Ueno, S.; Goessler, W.; Kuehnelt, D.; Schlagenhaufen, C.; Kaise, T.; Irgolic, K.J. Occurrence of organo-arsenicals in jellyfishes and their mucus. Chemosphere 2001, 44, 743-749. [CrossRef]

56. Pitt, K.A.; Welsh, D.T.; Condon, R.H. Influence of jellyfish blooms on carbon, nitrogen and phosphorus cycling and plankton production. Hydrobiologia 2009, 616, 133-149. [CrossRef]

57. Bythell, J.; Wild, C. Biology and ecology of coral mucus release. J. Exp. Mar. Biol. Ecol. 2011, 408, 88-93. [CrossRef]

58. Rivera Ortega, J. Actividad Antimicrobiana del Mucus de Cnidarios Simbióticos. Master's Thesis, National Autonomous University of Mexico, Puerto Morelos, Mexico, 2018.

59. Rottini Sandrini, L.; Avian, M. Reproduction of Pelagia noctiluca in the central and northern Adriatic Sea. Hydrobiologia 1991, 216, 197-202. [CrossRef]

60. Aglieri, G.; Papetti, C.; Zane, L.; Milisenda, G.; Boero, F.; Piraino, S. First evidence of inbreeding, relatedness and chaotic genetic patchiness in the holoplanktonic Jellyfish Pelagia noctiluca (Scyphozoa, Cnidaria). PLoS ONE 2014, 9, e99647. [CrossRef] [PubMed]

61. Ishii, H.; Båmstedt, U. Food regulation of growth and maturation in a natural population of Aurelia aurita (L.). J. Plankton Res. 1998, 20, 805-816. [CrossRef]

62. Fu, Z.; Shibata, M.; Makabe, R.; Ikeda, H.; Uye, S.-I. Body size reduction under starvation, and the point of no return, in ephyrae of the moon jellyfish Aurelia aurita. Mar. Ecol. Prog. Ser. 2014, 510, 255-263. [CrossRef]

63. Lucas, C.H. Reproduction and life history strategies of the common jellyfish, Aurelia aurita, in relation to its ambient environment. Hydrobiologia 2001, 451, 229-246. [CrossRef]

64. Brewer, R.H. The Annual Pattern of Feeding, Growth, and Sexual Reproduction in Cyanea (Cnidaria: Scyphozoa) in the Niantic River Estuary, Connecticut. Biol. Bull. 1989, 176, 272-281. [CrossRef]

65. Kremer, P. Effect of food availability on the metabolism of the ctenophore Mnemiopsis mccradyi. Mar. Biol. 1982, 71, 149-156. [CrossRef] 
66. Padilla-Serrato, J.G.; López-Martínez, J.; Acevedo-Cervantes, A.; Alcántara-Razo, E.; Rábago-Quiroz, C.H. Feeding of the scyphomedusa Stomolophus meleagris in the coastal lagoon Las Guásimas, northwest Mexico. Hidrobiológica 2013, 23, $218-226$.

67. Álvarez-Tello, F.J.; López-Martínez, J.; Lluch-Cota, D.B. Trophic spectrum and feeding pattern of cannonball jellyfish Stomolophus meleagris (Agassiz, 1862) from central Gulf of California. J. Mar. Biol. Assoc. U. K. 2016, 96, 1217-1227. [CrossRef]

68. Carvalho-Saucedo, L.; García-Domínguez, F.; Rodríguez-Jaramillo, C.; López-Martínez, J. Variación lipídica en los ovocitos de la medusa Stomolophus meleagris (Scyphozoa: Rhizostomeae), durante el desarrollo gonádico, en la laguna Las Guásimas, Sonora, México. Rev. Biol. Trop. 2010, 58, 119-130. [CrossRef] [PubMed]

69. Hamner, W.; Jenssen, R. Growth, Degrowth, and Irreversible Cell Differentiation in Aurelia aurita. Integr. Comp. Biol. 1974, 14, 833-849.

70. Raskoff, K.; Sommer, F.; Hamner, W.; Cross, K. Collection and Culture Techniques for Gelatinous Zooplankton. Biol. Bull. 2003, 204, 68-80. [CrossRef] [PubMed]

71. Niggl, W.; Naumann, M.S.; Struck, U.; Manasrah, R.; Wild, C. Organic matter release by the benthic upside-down jellyfish Cassiopea sp. fuels pelagic food webs in coral reefs. J. Exp. Mar. Biol. Ecol. 2010, 384, 99-106. [CrossRef]

72. Tinta, T.; Klun, K.; Herndl, G.J. The importance of jellyfish-microbe interactions for biogeochemical cycles in the ocean. Limnol. Oceanogr. 2021, 66, 2011-2032. [CrossRef]

73. Malej, A. Behaviour and trophic ecology of the jellyfish Pelagia noctiluca (Forsskål). J. Exp. Mar. Biol. Ecol. 1989, 126, 259-270. [CrossRef]

74. Jordano, M.; Morandini, A.; Nagata, R. Is phenotypic plasticity determined by temperature and fluid regime in filter-feeding gelatinous organisms? J. Exp. Mar. Biol. Ecol. 2019, 522, 151238. [CrossRef]

75. Frandsen, K.; Riisgård, H.U. Size dependent respiration and growth of jellyfish, Aurelia aurita. Sarsia 1997, 82, 307-312. [CrossRef]

76. Tills, O.; Sun, X.-X.; Rundle, S.; Heimbach, T.; Gibson, T.; Cartwright, A.; Palmer, M.; Rudin-Bitterli, T.; Spicer, J. Reduced pH affects pulsing behaviour and body size in ephyrae of the moon jellyfish, Aurelia aurita. J. Exp. Mar. Biol. Ecol. 2016, 480, 54-61. [CrossRef]

77. Aljbour, S.M.; Zimmer, M.; Kunzmann, A. Cellular respiration, oxygen consumption, and trade-offs of the jellyfish Cassiopea sp. in response to temperature change. J. Sea Res. 2017, 128, 92-97. [CrossRef]

78. López-Martínez, J.; Arzola-Sotelo, E.A.; Nevárez-Martínez, M.O.; Álvarez-Tello, F.J.; Morales-Bojórquez, E. Modeling growth on the cannonball jellyfish Stomolophus meleagris based on a multi-model inference approach. Hydrobiologia 2020, 847, 1399-1422. [CrossRef]

79. Dańko, A.; Schaible, R.; Dańko, M.J. Salinity Effects on Survival and Reproduction of Hydrozoan Eleutheria dichotoma. Estuaries Coasts 2020, 43, 360-374. [CrossRef] 